\title{
Removal of Cr(VI) from Aqueous Solutions Using Powder of Potato Peelings as a Low Cost Sorbent
}

\author{
Farai Mutongo, ${ }^{1}$ Olga Kuipa, ${ }^{1}$ and Pardon K. Kuipa ${ }^{1,2}$ \\ ${ }^{1}$ Department of Chemical Engineering, National University of Science and Technology, Bulawayo, Zimbabwe \\ ${ }^{2}$ School of Engineering Sciences and Technology, Chinhoyi University of Technology, Private Bag Box 7724, Chinhoyi, Zimbabwe \\ Correspondence should be addressed to Pardon K. Kuipa; kuipapardon@yahoo.com
}

Received 12 March 2014; Accepted 16 June 2014; Published 29 June 2014

Academic Editor: Zhe-Sheng Chen

Copyright (c) 2014 Farai Mutongo et al. This is an open access article distributed under the Creative Commons Attribution License, which permits unrestricted use, distribution, and reproduction in any medium, provided the original work is properly cited.

\begin{abstract}
Potato peels which are a low cost, renewable agroindustry by-product were used for the removal of hexavalent chromium from aqueous effluents. Batch experiments were carried out with an artificial effluent comprising of potassium dichromate in deionised water. The effects of the initial hexavalent chromium concentration, dose of biosorbent, and removal kinetics were explored. An adsorbent dosage of $4 \mathrm{~g} / \mathrm{L}$ was effective in complete removal of the metal ion, at $\mathrm{pH} 2.5$, in 48 minutes. The kinetic process of $\mathrm{Cr}(\mathrm{VI})$ adsorption onto potato peel powder was tested by applying pseudo-first-order and pseudo-second-order models as well as the Elovich kinetic equation to correlate the experimental data and to determine the kinetic parameters. The adsorption data were correlated by the Langmuir and Freundlich isotherms. A maximum monolayer adsorption capacity of $3.28 \mathrm{mg} / \mathrm{g}$ was calculated using the Langmuir adsorption isotherm, suggesting a functional group limited adsorption process. The results confirmed that potato peels are an effective biosorbent for the removal of hexavalent chromium from effluent.
\end{abstract}

\section{Introduction}

Wastewater from industries such as chrome leather tanning, metallurgy, chrome plating, textiles, ceramics, photography, and photoengraving contains moderate to excessive amounts of hexavalent chromium compounds beyond the conventional statutory limit of $0.1 \mathrm{mg} / \mathrm{L}$. Remediation of these effluents is necessary because in humans $\mathrm{Cr}(\mathrm{VI})$ causes lung cancer, ulcers, nasal septum perforations, and damage to the kidneys.

Established methods for the removal of chromium from wastewaters include precipitation, electrochemical reduction, ion exchange, electrodeposition, membrane technology, and adsorption. Adsorption remains one of the most economical and widely used method for the removal of toxic pollutants from wastewater and the most widely used $\mathrm{Cr}(\mathrm{VI})$ sorbent is activated carbon although it is expensive and has high running costs since it requires regeneration after sorption. Therefore the potential exists for $\mathrm{Cr}(\mathrm{VI})$ removal by a lower cost biosorbent. The use of nonliving biomass as metal binding compounds has gained popularity over the use of live biomass. This is mainly because living cells are subject to toxic effects of heavy metals, resulting in cell death. Living cells also require the addition of nutrients and hence increase the BOD and COD in the effluent. Dead cells on the other hand require little care and maintenance, are cheaper, and can be easily regenerated and reused.

The adsorption of $\mathrm{Cr}(\mathrm{VI})$ by a number of materials such as agroindustry waste residues [1-4], forestry waste $[5,6]$, fruit peelings and leaves [7-10], fungi $[11,12]$, dead bacterial, and diatom biomass [13-15] has been reported in the literature.

This study investigated the use of potato peels which are widely available in many countries as a biosorbent for a low cost $\mathrm{Cr}(\mathrm{VI})$ removal technology. The Langmuir and Freundlich isotherms were employed to analyse the equilibrium data. The Elovich, pseudo-first-order, and pseudo-secondorder kinetic models were used for the kinetic interpretation of the adsorption data. The effects of varying concentration of the chromium, contact time, and adsorbent dose were investigated.

\section{Materials and Methods}

2.1. Preparation of Chromium Solution and Analysis. A stock solution $(500 \mathrm{mg} / \mathrm{L})$ was prepared by dissolving $1.4144 \mathrm{~g}$ of 
AR grade potassium dichromate in one liter of deionised water. Experimental solutions of the desired concentrations were obtained from the stock solution by appropriate dilutions with deionised water. $\mathrm{Cr}(\mathrm{VI})$ was quantified using diphenylcarbazide (DPC) which forms a red violet complex whose intensity was read at $540 \mathrm{~nm}$ using a Hach Spectrophotometer (model DR 2010) as outlined in the Standard Methods for the Examination of Water and Wastewater handbook [16]. All glassware was cleaned with $6 \mathrm{~mol} / \mathrm{L} \mathrm{HCl}$ and then rinsed in deionised water.

2.2. Preparation of Biosorbent. Potato peels, referred to as biosorbent, were collected from a local food chain (Chicken Inn) free of charge and washed in deionized water and then rinsed in $0.1 \mathrm{M} \mathrm{HCl}$. In acidic media the surface of the sorbent is expected to be protonated to a large extent resulting in a stronger attraction for chromium oxyanions in the solution (in acidic media $\mathrm{Cr}(\mathrm{VI})$ exists in the form of oxyanions such as $\mathrm{HCrO}_{4}{ }^{-}, \mathrm{CrO}_{4}{ }^{-}, \mathrm{Cr}_{2} \mathrm{O}_{7}{ }^{2-}, \mathrm{Cr}_{3} \mathrm{O}_{10}{ }^{2-}$ ). The biosorbent was left to dry at approximately $103-110^{\circ} \mathrm{C}$ overnight in an oven. The dried biosorbent was then ground to $100 \%$ passing $75 \mu \mathrm{m}$ and stored in airtight plastic bottles prior to batch tests.

\section{Batch Biosorption Studies}

For all the batch biosorption studies blank experimental runs with only the adsorbent in $100 \mathrm{~mL}$ of distilled water were conducted simultaneously at similar conditions to account for any adsorbate leached by the adsorbents and adsorbed by the glass container walls. All batch experiments were carried out at $\mathrm{pH} 2.5$ and all mixtures were stirred by a magnetic stirrer at $300 \mathrm{rpm}$. The value of the $\mathrm{pH}$ was chosen based on previous research that reported that the point of zero charge for potato peel biomass is at $\mathrm{pH} 6.59$ [17], meaning that the biomass has an overall positive charge for $\mathrm{pH}$ values below 6.59 and starts to acquire an overall negative charge for $\mathrm{pH}$ values above 6.59. At $\mathrm{pH}$ values that are too low it is expected that hydronium ions, $\mathrm{H}_{3} \mathrm{O}^{+}$, would associate with the adsorbent surface sites thus restricting access to the surface sites by the metal ions through repulsive forces. A pH value of 2.5 was chosen to avoid metal ion precipitation. All experiments were conducted at ambient temperature $\left(27^{\circ} \mathrm{C}\right)$.

3.1. Effect of Absorbent Dose. Absorbent dose, varied from 0.5 to $4.0 \mathrm{~g} / \mathrm{L}$, was added to $100 \mathrm{~mL}$ of $40 \mathrm{mg} / \mathrm{L} \mathrm{K}_{2} \mathrm{Cr}_{2} \mathrm{O}_{7}$ in $100 \mathrm{~mL}$ volumetric flasks. The $\mathrm{pH}$ was adjusted to $2.5 \mathrm{using}$ $0.1 \mathrm{M} \mathrm{HCl}$. Approximately $10 \mathrm{~mL}$ of solution for analysis was withdrawn from each flask at 24-minute intervals and filtered. The filtrate from each flask was then analyzed for residual $\mathrm{Cr}(\mathrm{VI})$ concentration.

3.2. Effect of Initial Cr(VI) Concentration with Time. The initial concentration of the potassium dichromate solution was varied from 20 to $120 \mathrm{mg} / \mathrm{L}$. A constant absorbent dose of $4 \mathrm{~g} / \mathrm{L}$ was used for this set of experiments. The $\mathrm{pH}$ was adjusted to 2.5 using $0.1 \mathrm{M} \mathrm{HCl}$. The equilibrium curve was plotted from $\mathrm{Cr}(\mathrm{VI})$ percentage removal obtained after a time period of 148 minutes.

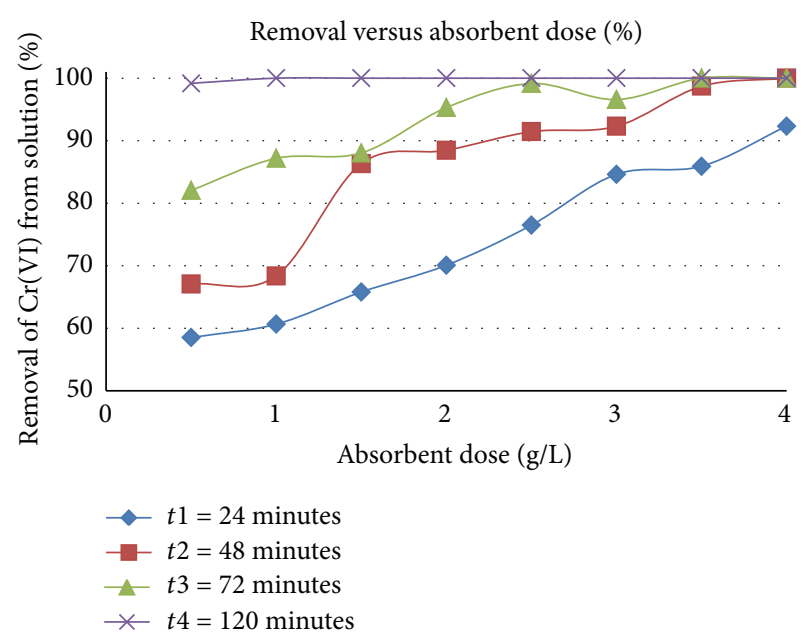

FIGURE 1: Effect of absorbent dose on \% $\mathrm{Cr}(\mathrm{VI})$ removal as a function of time, $\mathrm{pH} 2.5$, and initial $\mathrm{Cr}(\mathrm{VI})$ concentration of $40 \mathrm{mg} / \mathrm{L}$.

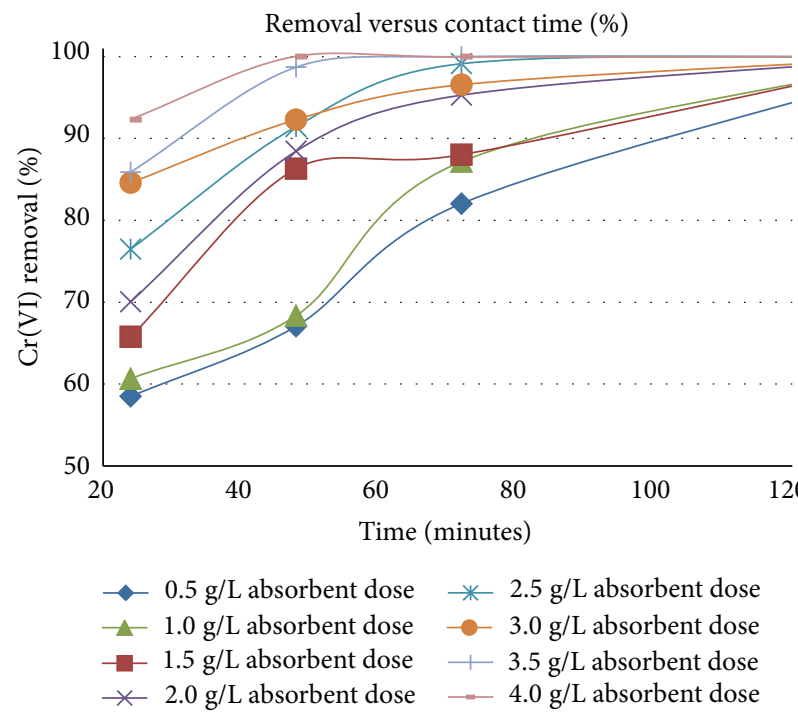

FIGURE 2: Effect of contact time on \% Cr(VI) removal, $\mathrm{pH} 2.5$, and initial $\mathrm{Cr}(\mathrm{VI})$ concentration of $40 \mathrm{mg} / \mathrm{L}$.

\section{Results and Discussion}

4.1. Effect of Absorbent Dose and Contact Time. Percentage removal of $\mathrm{Cr}(\mathrm{VI})$ from solution increased steadily with increase in absorbent dose and contact time (Figures 1 and 2). Complete removal is attained after only 48 minutes with a dosage of $4 \mathrm{~g} / \mathrm{L}$, whilst a dosage of $0.5 \mathrm{~g} / \mathrm{L}$ requires 120 minutes to attain $96 \pm 2 \%$ removal.

4.2. Effect of Initial Cr(VI) Concentration on Percent Removal. $\mathrm{Cr}(\mathrm{VI})$ sorption was studied in batch experiments $(\mathrm{pH} 2.5)$ using different initial Cr(VI) concentrations of 20, 40, 60, 100, and $120 \mathrm{mg} / \mathrm{L}$ (Figure 3).

Complete removal of $\mathrm{Cr}(\mathrm{VI})$ was attained for solutions up to $40 \mathrm{mg} / \mathrm{L}$. The "final equilibrium curve," was plotted from percentage removal obtained after a time period of 148 


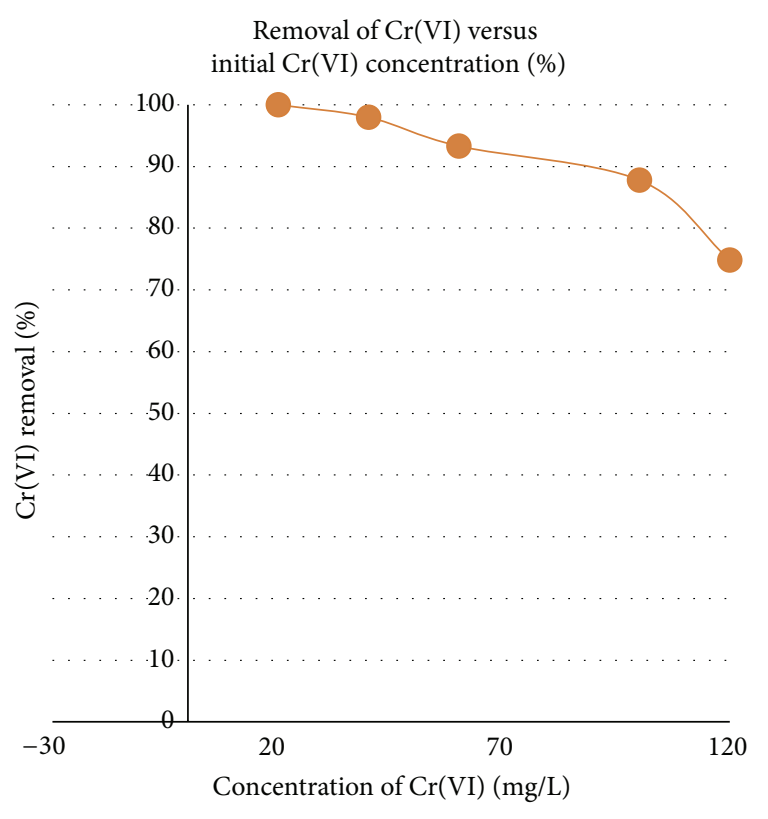

Equilibrium curve ( $t=148$ minutes)

Figure 3: Effect of initial Cr(VI) concentration, $\mathrm{pH} 2.5$, and absorbent dose of $4 \mathrm{~g} / \mathrm{L}$.

minutes. The equilibrium curve shows that the overall percent removal of $\mathrm{Cr}(\mathrm{VI})$ from solution decreases with an increase in initial $\mathrm{Cr}(\mathrm{VI})$ concentration. This may be attributed to lack of sufficient surface area to accommodate much more metal available in the solution. It is evident that the amount of chromium removed from solution increases with an increase in concentration of $\mathrm{Cr}(\mathrm{VI})$. This is probably due to the higher interaction between the metal ions and metal sequestering sites of the biosorbent. The final percentage removal for an initial chromium concentration of $120 \mathrm{mg} / \mathrm{L}$ was $74.84 \%$ whilst initial concentration of 100 and $60 \mathrm{mg} / \mathrm{L}$ saw a removal of $87.79 \%$ and $93.31 \%$, respectively.

\section{Adsorption Isotherm Investigation}

$\mathrm{Cr}(\mathrm{VI})$ uptake was calculated from mass balance, the difference between initial and final chromium concentrations:

$$
q\left(\mathrm{mg} \mathrm{g}^{-1}\right)=\frac{\left[C_{0}-C\right](\mathrm{mg} / \mathrm{L})}{m(\mathrm{~g})} V(\mathrm{~L})
$$

where $q$ is the metal uptake; $C_{0}$ and $C$ are the initial and final $\mathrm{Cr}(\mathrm{VI})$ concentration. $m$ is the mass of biosorbent and $V$ is the volume of solution used.

5.1. Langmuir Isotherm. The Langmuir equation refers to a monolayer sorption onto surfaces containing a finite number of accessible sites:

$$
q_{e}=\frac{q_{m} b C_{e}}{1+b C_{e}} .
$$

$b$ and $q_{m}$ are constants related to the apparent energy of sorption and the sorption capacity, respectively. $q_{e}$ is the amount absorbed per unit mass of the absorbent ( $\mathrm{mg} \mathrm{g}^{-1}$ ) with an equilibrium concentration of $C_{e}\left(\mathrm{mg} \mathrm{L}^{-1}\right)$. The values of $b$ and $q_{m}$ were calculated from the slope and intercept of the linear plot of $C_{e} / q_{e}$ versus $C_{e}$ :

$$
\frac{C_{e}}{q_{e}}=\frac{1}{b q_{m}}+\frac{C_{e}}{q_{m}} .
$$

The regression equation obtained is

$$
\begin{gathered}
y=0.305 x+0.680, \\
R^{2}=0.973,
\end{gathered}
$$

the constants $q_{m}=3.28 \mathrm{mg} / \mathrm{g}, b=0.448 \mathrm{~L} / \mathrm{mg}$.

The essential feature of the Langmuir isotherm model can be expressed by means of a separation factor or equilibrium parameter $\left(R_{L}\right)$ which is calculated as

$$
R_{L}=\frac{1}{1+b C_{0}} .
$$

The value of $R_{L}$ indicates the type of biosorption isotherm to be linear $\left(R_{L}=1\right)$, favourable $\left(0<R_{L}<1\right)$, unfavourable $\left(R_{L}>1\right)$, and irreversible $\left(R_{L}=0\right)$.

It can be noted that for this work, $R_{L}$ is favourable since both $b$ and $C_{0}$ are positive values, which indicates favourable biosorption of chromium by potato peel powder.

5.2. Freundlich Isotherm. The Freundlich isotherm model was applied to study the biosorption behavior assuming a heterogeneous adsorption surface and active sites with different energy and its linearized equation is

$$
\log q_{e}=\log K_{f}+n_{f} \log C_{e} .
$$

The Freundlich constants $k_{f}$ and $n_{f}$ are related to adsorption capacity and intensity, respectively, and were calculated from the slopes and intercept of the linear plot of $\log q_{e}$ versus $\log C_{e}$.

The linear regression equation obtained is given below with the calculated constants:

$$
\begin{gathered}
y=0.667 x-0.525, \\
R^{2}=0.974, \\
n_{f}=0.667, \quad K_{f}=0.2985 .
\end{gathered}
$$

$n_{f}$ lies between 0 and 1 indicating also favourable biosorption.

Both the Langmuir and the Freundlich adsorption models had a good fit to the equilibrium data which suggests that both monolayer and heterogeneous surface adsorption affect the biosorption.

\section{Kinetic Modelling}

6.1. Pseudo-First-Order Equation. Consider

$$
\frac{d q_{t}}{d t}=k_{1}\left(q_{e}-q_{t}\right)
$$




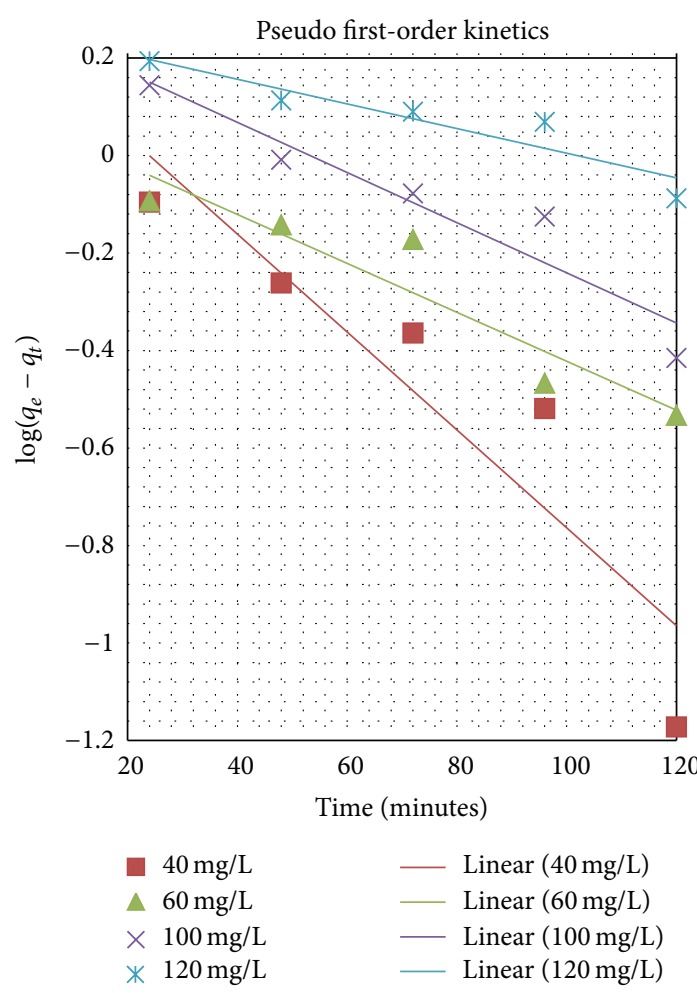

FIgURE 4: Pseudo-first-order kinetics, $\mathrm{pH}$ 2.5, ambient temperature, and $4 \mathrm{~g} / \mathrm{L}$ absorbent dose.

which on integration and simplification becomes

$$
\log \left(q_{e}-q_{t}\right)=\log q_{e}-\frac{k_{1}}{2.303} t,
$$

where $q_{t}(\mathrm{mg} / \mathrm{g})$ is the metal uptake at time $t,(\mathrm{~min}),. q_{e}$ is the metal uptake at equilibrium, and $k_{1}$ is the pseudo-first-order kinetic model constant (min.). The values of $k_{1}$ and $q_{e}$ can be obtained from the slope and intercept of the plot of $\log \left(q_{e}-q_{t}\right)$ versus $t$, respectively (Figure 4 ). The results are summarised in Tables 1, 2(a), and 2(b).

\subsection{Pseudo-Second-Order Equation. Consider}

$$
\frac{d q_{t}}{d t}=k_{2}\left(q_{e}-q_{t}\right)^{2}
$$

And the linear form is

$$
\frac{t}{q_{t}}=\frac{1}{k_{2} q_{e}^{2}}+\frac{1}{q_{e}} \cdot t
$$

where $k_{2}$ is the pseudo-second-order kinetic constant $\left(\mathrm{g} \mathrm{mg}^{-1} \mathrm{~min}^{-1}\right) . k_{2}$ and $q_{e}$ can be calculated from the slope and intercept of the plot of $t / q_{t}$ versus $t$. The results are summarised in Table 1. Low correlation coefficients for the pseudo-second-order kinetics model suggest that the model is not applicable to $\mathrm{Cr}(\mathrm{VI})$ adsorption onto potato peel powder, implying that the rate limiting step is not chemical adsorption.

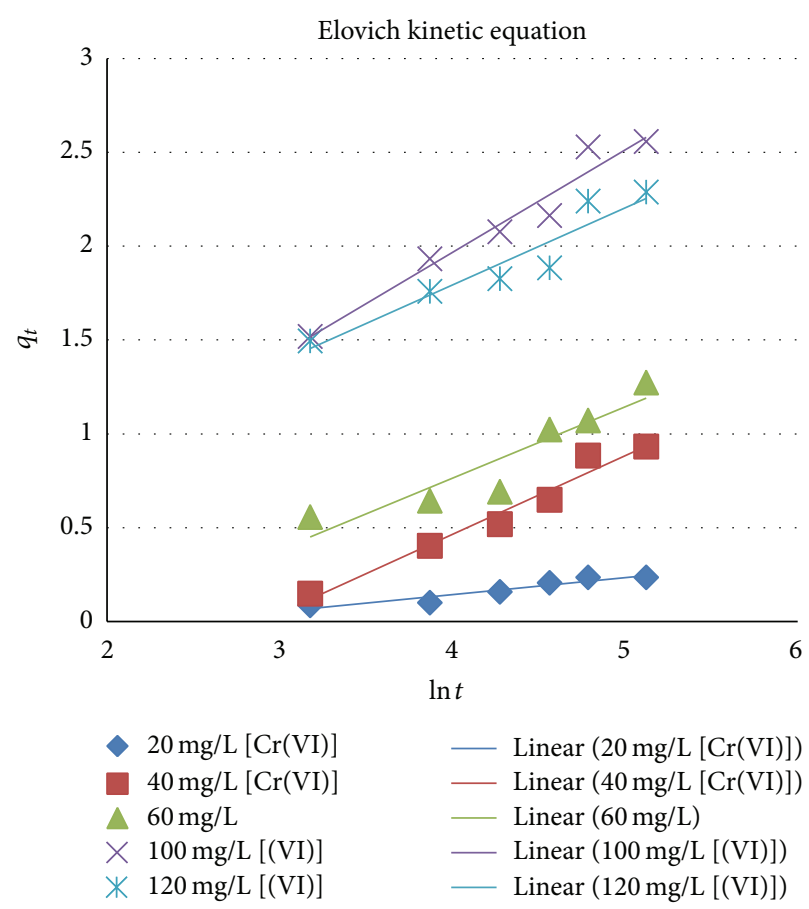

Figure 5: The Elovich kinetic model, $\mathrm{pH}$ 2.5, ambient temperature, and absorbent dose of $4 \mathrm{~g} / \mathrm{L}$.

6.3. Elovich Kinetic Equation. The Elovich kinetic equation is for general application to chemisorptions kinetics. It suggests that the active sites are heterogeneous in nature and therefore exhibit different activation energies for chemisorption. The equation is based on the adsorption capacity of the sorbent:

$$
\frac{d q_{t}}{d t}=\alpha \cdot \exp \left(-\beta q_{t}\right)
$$

where $q_{t}((\mathrm{~g} / \mathrm{kg}) / \mathrm{min})$ and $q_{e}$ is the metal uptake at equilib$\operatorname{rium}(\mathrm{mg} / \mathrm{g}), \alpha$ is the initial adsorption rate $\left(\mathrm{mg}^{-1} \mathrm{~g} \mathrm{~min}^{-1}\right)$, and $\beta$ is the desorption constant $\left(\mathrm{g} \cdot \mathrm{mg}^{-1}\right)$.

Simplification is attained by making the assumption, $\alpha \beta \gg t[18,19]$.

With boundary conditions $q_{t}=0, t=0, q_{t}=q_{t}$, and $t=t$,

$$
q_{t}=\frac{1}{\beta} \ln (\alpha \beta)+\frac{1}{\beta} \ln t
$$

The constants can be calculated from the slope and intercept of the plot of $q_{t}$ versus $\ln t$ (Figure 5). The results are summarised in Tables 1, 2(a), and 2(b).

\section{Comparison of the Present Study with Literature}

The data in Table 3 shows that there is a wide variation in the maximum absorption capacity of $\mathrm{Cr}(\mathrm{VI})$ by biosorbents (based on the Langmuir isotherm). The maximum adsorption capacity in this study is lower than that reported elsewhere in the literature [4]. 
TABLE 1: Regression equations and correlation factors using pseudo-first-order, pseudo-second-order, and Elovich kinetic models for the biosorption of $\mathrm{Cr}(\mathrm{VI})$ by waste potato peel.

\begin{tabular}{llll}
\hline$[\mathrm{Cr}(\mathrm{VI})] \mathrm{mg} / \mathrm{L}$ & Pseudo-first-order kinetics & Pseudo-second-order kinetics & Elovich kinetics \\
\hline \multirow{2}{*}{40} & $y=-0.01 x+0.274$ & $y=-0.569 x+223.9$ & $y=0.418 x-1.217$ \\
& $\mathbf{R}^{2}=\mathbf{0 . 8 4 2}$ & $R^{2}=0.153$ & $\mathbf{R}^{2}=\mathbf{0 . 9 6 5}$ \\
60 & $y=-0.005 x+0.080$ & $y=0.146 x+94.60$ & $y=0.380 x-0.757$ \\
& $\mathbf{R}^{2}=\mathbf{0 . 8 8 2}$ & $R^{2}=0.122$ & $\mathbf{R}^{2}=\mathbf{0 . 8 6 1}$ \\
100 & $y=-0.005 x+0.274$ & $y=0.114 x+36.64$ & $y=0.410 x+0.149$ \\
& $\mathbf{R}^{2}=\mathbf{0 . 9 0 6}$ & $R^{2}=0.139$ & $\mathbf{R}^{2}=\mathbf{0 . 9 0 2}$ \\
120 & $y=-0.002 x+0.257$ & $y=0.084 x+46.70$ & $y=0.546 x-0.218$ \\
& $\mathbf{R}^{2}=\mathbf{0 . 8 7 0}$ & $R^{2}=0.048$ & $\mathbf{R}^{2}=\mathbf{0 . 9 5 6}$ \\
\hline
\end{tabular}

TABLE 2: (a) Kinetic parameters for the adsorption of $\mathrm{Cr}(\mathrm{VI})$ onto potato peel powder at $T=27^{\circ} \mathrm{C}$. (b) Averaged kinetic parameters for the adsorption of $\mathrm{Cr}(\mathrm{VI})$ onto potato peel powder at $T=27^{\circ} \mathrm{C}$.

(a)

\begin{tabular}{|c|c|c|c|c|}
\hline Kinetic model & Linear equation & $\begin{array}{c}\text { Initial } \mathrm{Cr}(\mathrm{VI}) \\
\text { concentration, } \mathrm{mg} / \mathrm{L}\end{array}$ & Reaction constant & $R^{2}$ \\
\hline \multirow{4}{*}{ Pseudo-first-order } & \multirow{4}{*}{$\log \left(q_{e}-q_{t}\right)=\log q_{e}-\frac{k_{1}}{2.303} t$} & 40 & $k_{1}=0.0230 \mathrm{~min}^{-1}$ & 0.842 \\
\hline & & 60 & $k_{1}=0.0115 \mathrm{~min}^{-1}$ & 0.882 \\
\hline & & 100 & $k_{1}=0.0115 \mathrm{~min}^{-1}$ & 0.906 \\
\hline & & 120 & $k_{1}=0.0046 \mathrm{~min}^{-1}$ & 0.870 \\
\hline \multirow{5}{*}{ Elovich } & \multirow{5}{*}{$q_{t}=\frac{1}{\beta} \ln (\alpha \beta)+\frac{1}{\beta} \ln t$} & 20 & $\begin{array}{l}\alpha=0.0081 \mathrm{mg} \cdot \mathrm{g}^{-1} \cdot \mathrm{min}^{-1} \\
\beta=11.11 \mathrm{~g} / \mathrm{mg}\end{array}$ & 0.907 \\
\hline & & 40 & $\begin{array}{l}\alpha=0.0227 \mathrm{mg} \cdot \mathrm{g}^{-1} \cdot \mathrm{min}^{-1} \\
\beta=2.3923 \mathrm{~g} / \mathrm{mg}\end{array}$ & 0.965 \\
\hline & & 60 & $\begin{array}{l}\alpha=0.0518 \mathrm{mg} \cdot \mathrm{g}^{-1} \cdot \mathrm{min}^{-1} \\
\beta=2.6316 \mathrm{~g} / \mathrm{mg}\end{array}$ & 0.861 \\
\hline & & 100 & $\begin{array}{l}\alpha=0.5897 \mathrm{mg} \cdot \mathrm{g}^{-1} \cdot \mathrm{min}^{-1} \\
\beta=2.4390 \mathrm{~g} / \mathrm{mg}\end{array}$ & 0.902 \\
\hline & & 120 & $\begin{array}{l}\alpha=0.3663 \mathrm{mg} \cdot \mathrm{g}^{-1} \cdot \mathrm{min}^{-1} \\
\beta=1.8315 \mathrm{~g} / \mathrm{mg}\end{array}$ & 0.956 \\
\hline
\end{tabular}

(b)

\begin{tabular}{lll}
\hline Kinetic model & Linear equation & Reaction constant \\
\hline Pseudo-first-order & $\log \left(q_{e}-q_{t}\right)=\log q_{e}-\frac{k_{1}}{2.303} t$ & $k_{1}=0.01267 \pm 0.00764 \mathrm{~min}^{-1}$ \\
Elovich & $q_{t}=\frac{1}{\beta} \ln (\alpha \beta)+\frac{1}{\beta} \ln t$ & $\alpha=0.25763 \pm 0.3440 \mathrm{mg} \cdot \mathrm{g}^{-1} \cdot \mathrm{min}^{-1}$ \\
& & $\beta=2.3236 \pm 0.27054 \mathrm{~g} / \mathrm{mg}$ \\
\hline
\end{tabular}

\section{Conclusions}

When applying the Langmuir isotherm to the adsorption data, a maximum monolayer adsorption capacity of $3.28 \mathrm{mg} / \mathrm{g}$ suggests a functional group limited adsorption process. Indeed potato peel has been reported [23] to be a source of phenolic compounds, glycoalkaloids, and cell wall polysaccharides. These compounds would be the source of the functional groups. The value of the adsorption energy, $b$, was found to be $0.448 \mathrm{~L} / \mathrm{mg}$. When the adsorption data are modeled using the Freundlich isotherm, the equilibrium constant, $K_{f}$, is found to be $0.2985\left((\mathrm{mg} / \mathrm{g})(\mathrm{L} / \mathrm{mg})^{1 / n}\right)$. The value of $n$ was $2 / 3$, which is between 0 and 10 , suggesting relatively strong adsorption of $\mathrm{Cr}(\mathrm{VI})$ ions onto the surface of the potato peel powder. Low correlation coefficients for the pseudo-second-order kinetics model suggest that the model is not applicable to $\mathrm{Cr}(\mathrm{VI})$ adsorption onto potato peel powder, implying that the rate limiting step is not chemical adsorption. Relatively high correlation coefficients $\left(R^{2}\right)$ for the pseudo-first-order model and the Elovich kinetic equation suggest that these models can adequately describe the kinetic process of $\mathrm{Cr}(\mathrm{VI})$ adsorption onto potato peel powder. Applicability of the Elovich model implies that the active sites of the potato peel powder are heterogeneous in nature and therefore exhibit different activation energies for chemisorption. In general, it may be concluded that the use of potato peel powder is an effective method for the abatement of $\mathrm{Cr}(\mathrm{VI})$ aqueous contaminants. 
TABLE 3: Comparison between the results of this work and other results found in the literature for the monolayer maximum adsorption capacity of $\mathrm{Cr}(\mathrm{VI})$ ions with various adsorbents.

\begin{tabular}{|c|c|c|}
\hline Biosorbent & $Q_{m}(\mathrm{mg} / \mathrm{g})$ & Reference \\
\hline Agave lechuguilla & 33.55 & {$[18]$} \\
\hline Brown seaweed & 0.629 & {$[20]$} \\
\hline Maize husk & 28.49 & {$[2]$} \\
\hline Maize bran & 312.52 & {$[3]$} \\
\hline Potato peel waste & 8.012 & {$[4]$} \\
\hline Psidium guajava leaves powder & 4.762 & {$[8]$} \\
\hline Modified pomegranate peel & 13.01 & [9] \\
\hline $\begin{array}{l}\text { Formaldehyde modified pomegranate } \\
\text { peel }\end{array}$ & 22.28 & [9] \\
\hline Powder of mosambi fruit peel & 7.51 & {$[10]$} \\
\hline Acacia nilotica leaf & 69.4 & {$[5]$} \\
\hline Pine cone and oak cups & $\begin{array}{c}\text { Ranges from } \\
4.19 \text { to } 7.48\end{array}$ & {$[6]$} \\
\hline Pine leaves & 0.198 & [7] \\
\hline Sawdust & 0.470 & [7] \\
\hline Raw and modified palm branches & 55.0 & [21] \\
\hline $\begin{array}{l}\text { Dried biomass of cyanobacterium } \\
\text { Oscillatoria laetevirens }\end{array}$ & 103.09 & {$[13]$} \\
\hline Diatom Planothidium lanceolatum & 93.45 & {$[14]$} \\
\hline Biomass of Trichoderma gamsii & 44.8 & {$[15]$} \\
\hline $\begin{array}{l}\text { Dead biomass of green algae Spirogyra } \\
\text { spp. }\end{array}$ & 265.0 & {$[22]$} \\
\hline Tea fungus & 58.0 & {$[11]$} \\
\hline Trametes versicolor Polyporus fungi & 125.0 & {$[12]$} \\
\hline Potato peel powder & 3.28 & $\begin{array}{l}\text { Present } \\
\text { Study }\end{array}$ \\
\hline
\end{tabular}

\section{Conflict of Interests}

The authors declare that there is no conflict of interests regarding the publication of this paper.

\section{References}

[1] A. B. Sallau, S. Aliyu, and S. Ukuwa, "Biosorption of chromium (VI) from aqueous solution by corn cob powder," International Journal of Environment and Bioenergy, vol. 4, no. 3, pp. 131-140, 2012.

[2] A. A. Idowu, O. A. Edwin, I. M. Abidemi, A. S. Akinyeye, and S. O. Kareem, "Biosorption of Cr (VI) ion from aqueous solution by maize husk: isothermal, kinetics and thermodynamic study," Journal of the Chemical Society of Pakistan, vol. 34, no. 6, pp. 1388-1396, 2012.

[3] S. H. Hasan, K. K. Singh, O. Prakash, M. Talat, and Y. S. Ho, "Removal of $\mathrm{Cr}(\mathrm{VI})$ from aqueous solutions using agricultural waste 'maize bran"' Journal of Hazardous Materials, vol. 152, no. 1, pp. 356-365, 2008.

[4] M. A. Abdullah and A. G. D. Prasad, "Kinetics and equilibrium studies for the biosorption of $\mathrm{Cr}$ (VI) from aqueous solutions by potato peel waste," International Journal of Chemical Engineering Research, vol. 1, no. 2, pp. 51-62, 2009.
[5] A. L. Prasad and S. Thirumalisamy, "Evaluation of the use of Acacia nilotica leaf as an ecofriendly adsorbent for Cr (VI) and its suitability in real waste water: study of residual errors," Journal of Chemistry, vol. 2013, Article ID 354328, 7 pages, 2013.

[6] N. Berraksu, E. M. Ayan, and J. Yanik, "Use of forestry wastes for biosorption of dyes and Cr (VI)," Journal of Chemistry, vol. 2013, Article ID 427586, 10 pages, 2013.

[7] M. Aliabadi, K. Morshedzadeh, and H. Soheyli, "Removal of hexavalent chromium from aqueous solution by lignocellulosic solid wastes," International Journal of Environmental Science and Technology, vol. 3, no. 3, pp. 321-325, 2006.

[8] C. DurgaPrasad, P. S. P. Krishna, and C. Srinivas, "Equilibrium studies on biosorption of chromium on Psidium guajava leaves powder," Journal of Chemical and Pharmaceutical Research, vol. 4, no. 4, pp. 1868-1879, 2012.

[9] T. S. Najim and S. A. Yassin, "Removal of Cr(VI) from aqueous solution using modified pomegranate peel: equilibrium and kinetic studies," E-Journal of Chemistry, vol. 6, supplement 1, pp. S129-S142, 2009.

[10] R. Hema Krishna and A. V. V. S. Swamy, "Studies on removal of $\mathrm{Cr}$ (VI) from aqueous solutions using powder of mosambi fruit peelings (PMFP) as a low cost sorbent," E-Journal of Chemistry, vol. 9, no. 3, pp. 1389-1399, 2012.

[11] M. B. Šćiban, J. M. Prodanović, and R. N. Razmovski, "Biosorption of copper(II) and chromium(VI) by modified tea fungus," Acta Periodica Technologica, no. 43, pp. 335-342, 2012.

[12] M. V. Subbaiah, S. Kalyani, G. S. Reddy, V. M. Boddu, and A. Krishnaiah, "Biosorption of $\mathrm{Cr}(\mathrm{VI})$ from aqueous solutions using trametes versicolor polyporus fungi," E-Journal of Chemistry, vol. 5, no. 3, pp. 499-510, 2008.

[13] D. Suman, "Biosorption of chromium and nickel by dried biomass of cyanobacterium Oscillatoria laete-virens," International Journal of Environmental Science, vol. 3, no. 1, pp. 341-352, 2012.

[14] K. Sbihi, O. Cherifi, and M. Bertrand, "Toxicity and biosorption of chromium from aqueous solutions by the diatom Planothidium lanceolatum (Brébisson) Lange-Bertalot," American Journal of Scientific and Industrial Research, vol. 3, no. 1, pp. 27-38, 2012.

[15] B. Kavita and H. Keharia, "Biosorption potential of Trichoderma gamsii biomass for removal of $\mathrm{Cr}(\mathrm{VI})$ from electroplating industrial effluent," International Journal of Chemical Engineering, vol. 2012, Article ID 305462, 7 pages, 2012.

[16] L. S. Clesceri, A. E. Greenberg, and A. D. Eaton, Eds., Standard Methods for the Examination of Water and Wastewater, APHA, WEF, AWWA, American Public Health Association, Washington, DC, USA, 20th edition, 1998.

[17] M. R. Samarghandy, E. Hoseinzade, M. Taghavi, and S. Hoseinzadeh, "Biosorption of reactive black 5 from aqueous solution using acid-treated biomass from potato peel waste," BioResources, vol. 6, no. 4, pp. 4840-4855, 2011.

[18] C. W. Cheung, J. F. Porter, and G. McKay, "Sorption kinetics for the removal of copper and zinc from effluents using bone char," Separation and Purification Technology, vol. 19, no. 1-2, pp. 5564, 2000.

[19] S. H. Chien and W. R. Clayton, "Application of Elovich equation to the kinetics of phosphate release and sorption in soils," Soil Science Society of America Journal, vol. 44, no. 2, pp. 265-268, 1980.

[20] J. Romero-González, J. L. Gardea-Torresdey, J. R. Peralta-Videa, and E. Rodríguez, "Determination of equilibrium and kinetic 
parameters of the adsorption of $\mathrm{Cr}$ (III) and $\mathrm{Cr}$ (VI) from aqueous solutions to Agave lechuguilla Biomass," Bioinorganic Chemistry and Applications, vol. 2005, no. 1-2, pp. 55-68, 2005.

[21] M. A. Shouman, N. A. Fathy, S. A. Khedr, and A. A. Attia, "Comparative biosorption studies of hexavalent chromium ion onto raw and modified palm branches," Advances in Physical Chemistry, vol. 2013, Article ID 159712, pp. 1-9, 2013.

[22] A. Yaqub, M. S. Mughal, A. Adnan, W. A. Khan, and K. M. Anjum, "Biosorption of hexavalent chromium by Spirogyra spp.: equilibrium, kinetics and thermodynamics," The Journal of Animal and Plant Sciences, vol. 22, no. 2, pp. 408-415, 2012.

[23] A. Schieber and M. D. A. Saldana, "Potato peels: a source of nutritionally and pharmacologically interesting compounds-a review," Food, vol. 3, no. 2, pp. 21-29, 2009. 

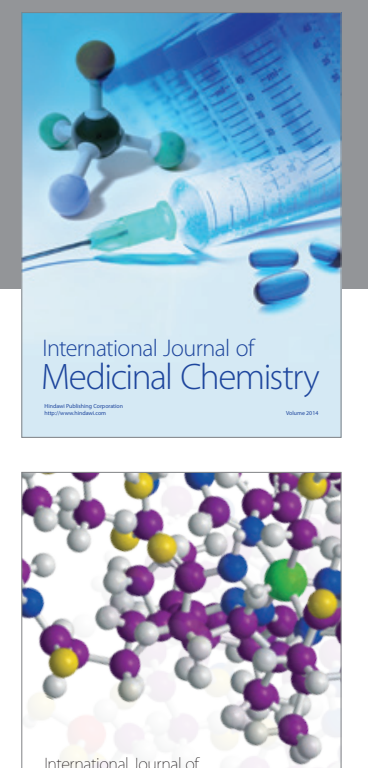

\section{Carbohydrate} Chemistry

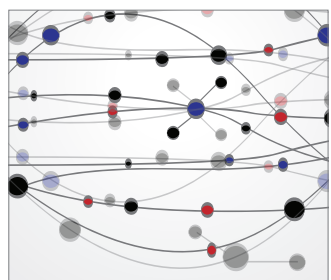

The Scientific World Journal
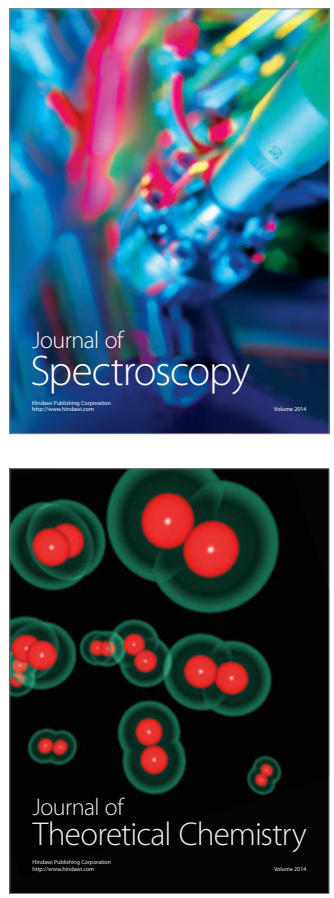
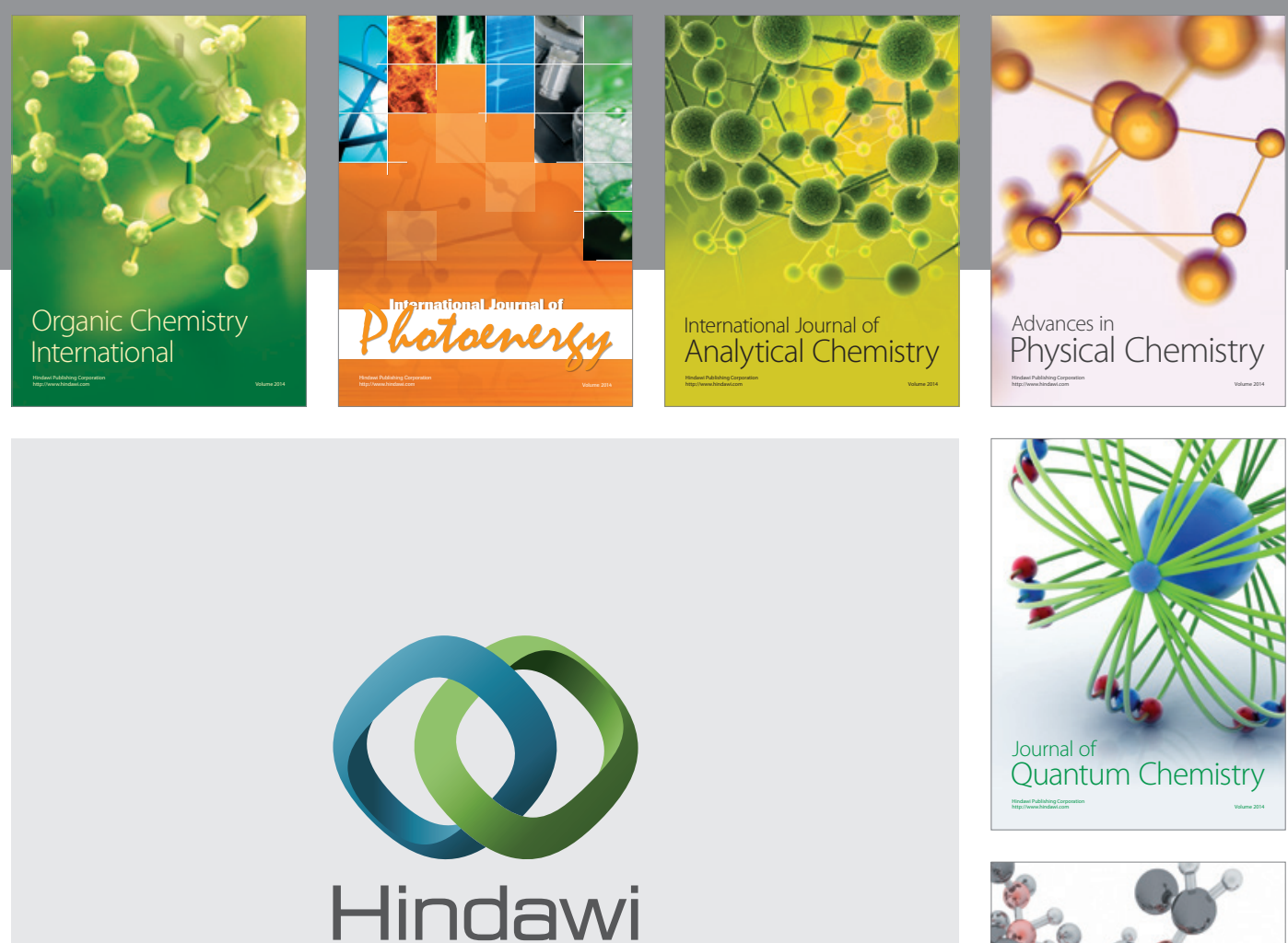

Submit your manuscripts at

http://www.hindawi.com

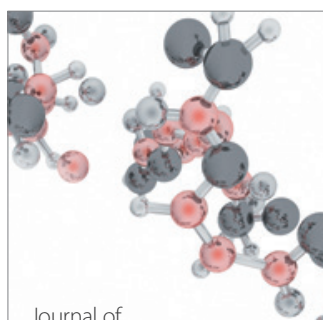

Analytical Methods

in Chemistry

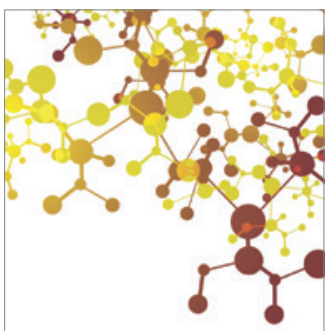

Journal of

Applied Chemistry

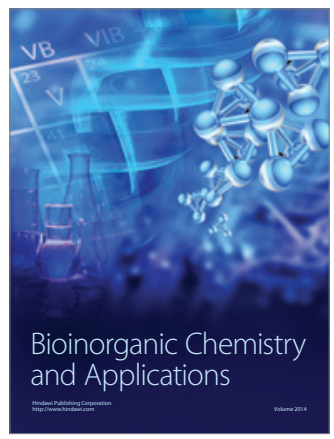

Inorganic Chemistry
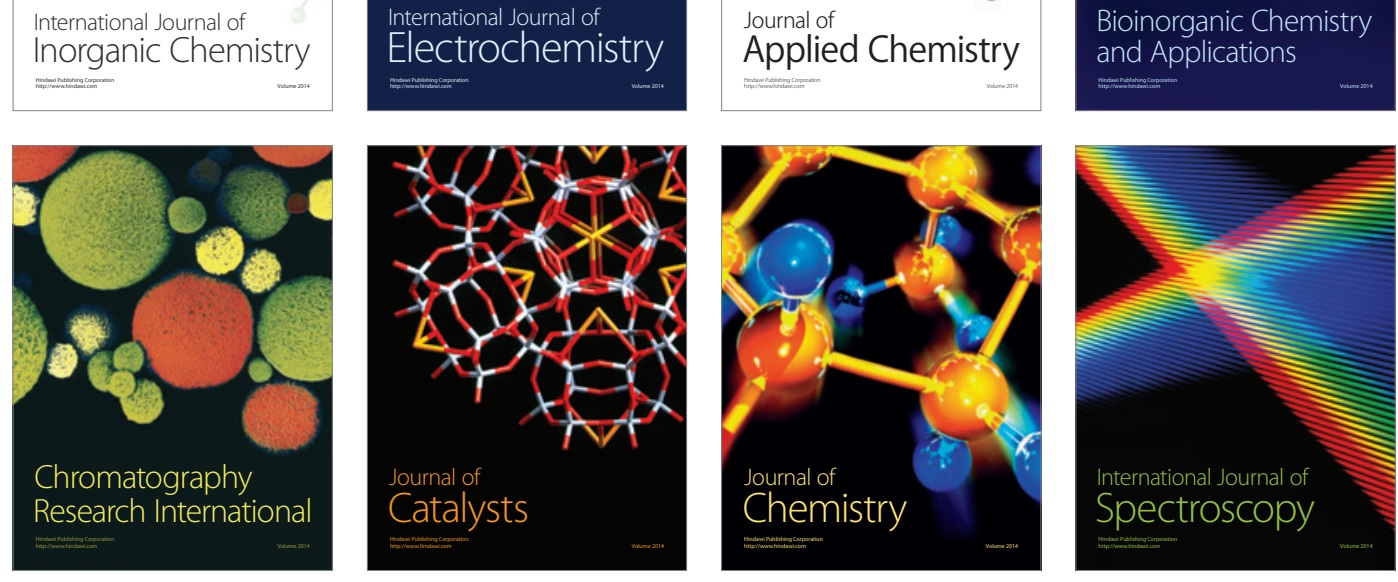